\title{
1. Stepping down rather than up: the ethical option for business in our troubling times
}

\section{Donna Ladkin}

In an interview with the New York Times in August of 2017, the Chief Executive of Apple Computers, Tim Cook was quoted to have said that because government was becoming 'less functional' and 'less able to work at the speed it once did', businesses and other areas of society needed to 'step up' to fulfil the roles that government once played (Sorkin, 2017). This chapter argues a contrary view: that the truly ethical response for business in our troubling times is to step 'down', rather than 'up'. The idea that corporations need to step up in order to fill a moral gap speaks to the assumption that they are now the prime actors within society whose operational approaches will best serve society at large. Secondly, it assumes that businesses, rather than elected government officials, are best placed to decide how to serve wider societal interests. Furthermore, it intimates that businesses themselves can choose the ways of stepping up that suit them best. This is clearly the case for Apple, who donated \$10 million to hurricane relief in 2017 (Mejia, 2017) but simultaneously holds over $\$ 252$ billion in offshore accounts in order not to pay tax on these profits (Drucker and Bowen, 2017).

Stepping down, that is, businesses taking a place as one voice among many rather than assuming the role of central actors in society, offers a direct challenge to the neoliberal ideology of our times. Neoliberalism places market mechanisms and the pursuit of profit as central to human endeavour. As primary players within markets businesses have become dominant actors whose interests trump all others (Klein, 2014). Cook's statement speaks of the hubris that attends principal and privileged positions. Indeed, corporations' central position is so unequivocally dominant that Cook's statement is interpreted as an indication of his intent to take a moral lead, rather than as a practice of applying bandaids to good causes (as well as a step which attracts favourable media attention). 
From a practical perspective the chapter argues that stepping down would involve fulfilling the basic civic obligations of a commercial operation (such as paying tax, something that Apple assiduously avoids through holding greater offshore cash reserves than any other non-financial-based company in the world; Webb and Gurman, 2018) reducing the waste products it creates (Apple is currently under investigation by the French government for 'planned obsolescence', which drives consumer need to buy new phones; BBC, 2018) and creating an organizational culture in which work is only one aspect of employees' balanced life, leaving them free to create further value for themselves through family and community relationships (another aspect on which Apple falls down badly with employees citing experiences of working in a high stress, competitive environment; Ehrenkranz, 2016).

Rather than offering the 'band-aid' remedy of corporate social responsibility or even business ethics, the chapter proposes a radical reorientation of the relationship between businesses and governments. If Milton Friedman's assertion that the ethical responsibility of an organization is to increase shareholder wealth (Friedman, 1970) this drive needs to be balanced against other societal projects that protect and support those who are not shareholders: workers, those living in communities in which companies do their business, and most importantly, future generations of the planet.

The chapter proceeds as follows. Firstly, three key aspects of our troubling times are highlighted: the growing disparity in wealth distribution apparent throughout the USA and Europe, global climate change, and the rise of populism and with it the rise in hostile factionalism. Each of these is shown to be linked to neoliberal ideology. The growth of business ethics and corporate social responsibility as ethical responses to corporate wrongdoing is reviewed and critiqued. The argument then turns to consider the basics of corporate ethical responsibility and ends with the question of why these basics - paying an appropriate level of tax, safeguarding the environment in which the firm is situated, and placing the wellbeing of employees above the profit of the corporation - have become such radical base line requirements. The argument begins by identifying key aspects of our 'troubling times'.

\subsection{CHARACTERISTICS OF OUR 'TROUBLING TIMES'}

Our times are indeed troubled, and these difficulties are taking their toll on human beings in a number of ways. For instance, the incidence of suicide 
has risen by 25 per cent in the USA over the last two decades (Vance, 2018). The use of opiates and opiate-related death has increased five times from 1999 to 2016 (CDC, 2018) and in the USA, one out of every five people is diagnosed as suffering from anxiety or other mental health disorders (NAMI, 2018). Among the factors contributing to this worrying trend in human suffering are cited increased isolation and social fragmentation, heightened fear and the breakdown of family, and religious identification. Here I focus on three factors which go beyond the personal, yet also affect individuals' sense of security and happiness. These are: the growing disparity between the wealthy and the poor throughout the world but in the USA and UK in particular, climate change and environmental degradation, and the rise of populism which seems to be normalizing acts of racism and hostility in the USA and UK (Sidahmed, 2016; Weaver, 2018).

\subsubsection{Growing Disparity between Wealthy and Poor}

Writing for the National Bureau of Economic Research, Wolff (2017) notes the exponential growth of disparity in wealth distribution in the USA since the 1970s. His statistics indicate that the richest 1 per cent of Americans now hold more wealth that the combined 90 per cent below them. Hardest hit by the reduction in wealth has been the middle class, whose median household wealth in 2017 was equivalent to that in 1969. Although other developed economies are following this trend (for instance, the UK's progressive thinktank the Institute for Public Policy Research writes that in 2018, 44 per cent of the UK's wealth is held by the top 10 per cent of the population; Colebrook, 2018), Wolff asserts that 'By almost any conceivable index - household income, equivalent income, poverty, and household wealth, the US is now the most unequal country (or nearly so) among the advanced industrialised nations of the world' (p. xiv).

Ironically, such large wealth distribution is itself linked to a slowdown in the economy (Stockhammer, 2015). There is much evidence to suggest that wealth disparity is detrimental to societies in which there are such large distinctions between the rich and the poor. The social ills caused by such unequal holding of wealth include increased levels of poverty, homelessness and social unrest as well as rising levels of criminal activity. Other detrimental effects include vast differences in the health of the poor, even in wealthy countries (Coburn, 2000), depression, especially among women (Belle and Doucet, 2003), and impacts on happiness (Graham and Felton, 2006). Indeed, Wilkinson and Pickett (2009) argue in their study of the relationship between national economies and wellbeing statistics that life expectancy, levels of mental illness, violence and illiteracy are all a function not of how wealthy a country is, but of the equality of its wealth distribution. 


\subsubsection{Climate Change}

There is now little doubt among climate scientists that global temperatures are rising due to human activities, particularly the release of $\mathrm{CO}_{2}$ as a bi-product of the burning of fossil fuels into the environment (IPCCC, 2018). The most recent report by the Intergovernmental Panel on Climate Change suggests that if we are able to halt temperature rise at 1.5 degrees Celsius, we will avert the very worst of climate change effects. Their report stresses that doing so will require "rapid and far-reaching" transitions in land, energy, industry, buildings, transport, and cities. Global net humancaused emissions of carbon dioxide $\left(\mathrm{CO}_{2}\right)$ would need to fall by about 45 percent from 2010 levels by 2030, reaching "net zero" around 2050" (IPCC, 2018). However, although the deadline for halting that scenario has been variously set at 2017,2020 or 2030 - apart from a dip in fossil fuel consumption after the 2007-08 global financial crisis, emissions have continued to rise (Klein, 2014).

Climate change is probably the most troubling of all aspects of our current times, in that ultimately it threatens the viability of life on Earth. Within the northern hemisphere its effects have largely been experienced through the increase in the number and ferocity of storms. However, the southern hemisphere and on islands rising sea levels, desertification and disruption of seasonal weather patterns are already contributing to the loss of human as well as other life forms. It is estimated that should temperatures rise by 4 or even 6 degrees Celsius life as we know it will no longer be possible on the planet.

We do not have to wait to see the effects of climate change. It is already resulting in parts of the world becoming uninhabitable due to heat, desertification or rising seas. This is forcing people to move from their homelands, at a time when populist sentiment which is taking hold throughout Western Europe as well as the USA means legal immigration is increasingly difficult.

\subsubsection{The Rise of Populism}

The shocking result of the UK referendum in 2016 to leave the European Union, along with the election of Donald Trump as president of the USA have been cited as the result of populism expressing itself through democratic means (Cox, 2017). These occurrences are underpinned by increasing numbers of people who are feeling confident to express isolationist, anti-immigrant sentiments. After both the UK referendum and the election of Donald Trump incidences of hate crimes in the UK and the USA spiked dramatically. It has been argued (Klein, 2014; Korten, 1995) that 
these three issues (the results of the UK referendum and US election, the rise of populism and the increase in hate crime) are all linked, but also that they have their roots in the dominant ideology of our times: neoliberalism.

Contemporary business models, fixations and assumptions are all underpinned by this ideology which sees market mechanisms as the panacea to all society's ills. This taken-for-granted assumption informs the kind of managerialism to which public sector provisions such as healthcare, education and social services are now subject. The predominant business view that human beings can be treated as cogs in machines (which can be dispensed with in order to cut costs) has limitations when applied within institutions where care, time and genuine human contact are essential. The next section of the chapter examines neoliberalism and draws the connections between it and these worrying aspects of our contemporary context.

\subsection{WHAT IS NEOLIBERALISM?}

It is important to place neoliberalism within its own socio-historic context. Hamann (2009) explains that neoliberalism was a reaction to the over-involvement of government that had its most extreme expression in Stalinist Russia and Soviet-style communism, but could also be seen in elements of Roosevelt's New Deal liberalism. In its original form, neoliberalism was aligned with a sense of freedom from overly stringent government regulation. The unbiased 'invisible hand' of the market was idealized as a means of enabling maximum freedom to individuals, in which by pursuing individual interests the common good could be served (Smith, 1863). In order for this to work, human beings had to be reconceived as 'homo economicus'; creatures whose primary functions were economic, rather than aesthetic, communal or spiritual (Fleming, 2017).

Indeed, Hamann (2009, p. 38) writes that "neoliberalism strives to ensure that individuals are compelled to assume market-based values in all of their judgements and practices in order to amass sufficient quantities of "human capital"'. In this way we are all at the mercy of this ideology increasingly our very lives are things that we 'produce' and that accrue 'capital value'. This notion lends itself to the idea that those who do not accrue sufficient 'capital' can be considered 'waste' people (Hage, 2017) who do not have to be considered from a moral perspective.

Klein $(2014$, p. 9$)$ identifies three policy pillars of the neoliberal agenda: the privatization of the public sphere, deregulation of the corporate sector and lowering of corporation taxes - the last of which results in fewer funds being available for public spending. Tim Cook's assertion that government 
is no longer effective fails to recognize that a contributing factor to that lack of effectiveness is the reduction in funds governments have to work with as a result of the very generous corporate tax regulations that firms have enjoyed since the 1980s. Along with a reduced requirement to pay tax Hamann (2009) asserts that there is strong evidence that government policy in the USA is increasingly influenced by lobbyists agitating for corporate interests, which in turn revolve around short-term quarterly results. This is not a sound recipe for effective government.

\subsubsection{Effects of Neoliberalism}

Over 20 years ago, in his text When Corporations Rule the World, David Korten noted a three-fold human crisis: deepening poverty, environmental degradation and social disintegration (Korten, 1995). He traced the roots of these ills to economic models that make growth the goal of development and treat people as the means by which wealth can be generated (rather than beings for whom wealth is generated). The economic model of which Korten is critical is, of course, capitalism. Whereas before the fall of the Soviet Union, capitalism was recognized as one of a number of potential economic systems, in today's context it is commonly accepted to be the dominant (and indeed only workable) economic system. Such a view is supported by the growth of neoliberal ideology.

The way in which neoliberalism has undermined government is perhaps most explicitly exemplified in the fact that Donald Trump, a rather dubious businessman, but a businessman nonetheless, was elected to be the 45 th president of the USA. Qualities normally associated with the presidential role - prior experience in government, diplomacy, statesmanship or even common decency - have been eschewed in favour of a man who is perceived to be a 'successful businessman', largely because of the role he played on the reality television show The Apprentice (Schrodt, 2016). His promise to 'Make America Great Again' aligns with a populous who are seeking economic success in line with the American dream (Ladkin, 2017). What is not being so readily recognized is the way in which neoliberal policies tend to concentrate wealth in the hands of those who are already wealthy, rather than trickling down to those in middle and lower middleincome brackets.

Although the rhetoric of neoliberalism has a seductive element (if you work hard, you too can become a billionaire), the evidence of the last 30 years indicates that neoliberal policies result in rather different outcomes for the majority of us (Clifford, 2018). In particular, deregulation of markets and free trade agreements enable corporations to operate wherever they can employ the cheapest labour. This free movement has destroyed 
local communities who previously could rely on local manufacturing for employment, thus fuelling the conditions for rising populism. The fantasy of cheap goods is underwritten by huge costs to the environment in transportation costs. Interestingly, the carbon emissions that are produced through transporting goods when they are in international waters do not register on any country's carbon account sheet. Fossil fuels are subsidized by governments and the vicious circle is that fossil fuel companies donate so much money to political campaigns that politicians have to dance to their tune. These issues - wealth disparity, populism and environmental degradation - are all connected (Klein, 2014).

For instance, while enormous wealth has been created in the USA and Europe since the end of the Second World War, that wealth is not distributed evenly. One of the reasons for this is that for many organizations, their prime purpose is financial, rather than being in any way social. Reducing costs has therefore become the focus of much corporate activity, whether through moving operations to cheaper countries or increased levels of automation. This has had significant consequences for potential employees in the USA. For instance, Fort et al. (2018) note that although there has been a steady rise in the real wealth of manufacturing firms in the USA since 2000, employment has simultaneously fallen by 25 per cent. Manufacturing businesses are getting wealthier, while the human beings who were once employed by these businesses are not.

At the heart of wealth disparity is the way in which capitalist-based economics works. Businesses may be perceived to be central to generating that all important economic growth, but at what cost to human persons? Who should that growth be for, after all? Preferential tax treatment as well as limitless constraints on lobbying and supporting elected officials mean that business values, rather than human values, drive much of contemporary discourse. Businesses have indeed already 'stepped up' beyond their roles as providers of goods, services and meaningful work. The neoliberal ideology means they are no longer means for serving human purposes, but have become sumps for the top 1 per cent of the wealth-holding population.

\subsection{THE BUSINESS ETHICS AND CORPORATE SOCIAL RESPONSIBILITY RESPONSE}

It is interesting to note how as corporate malfeasance has been on the rise, a key response within the community of those responsible for developing managers is to promote the benefits of 'business ethics' courses and 'corporate social responsibility' (CSR). Indeed, Fleming et al. (2013, p. 339) assert that 'while companies are proclaiming [their virtues] on a scale 
never before seen, the "business as usual" mentality now feels completely entrenched and immovable'. Certainly, there is mixed evidence about the extent to which business ethics interventions influence corporate behaviour, with Boda and Zsolnai (2016) suggesting that as a project, business ethics has failed. A number of empirical studies have been undertaken in which MBA students or undergraduate business majors have been tested for their ethical awareness before and after being exposed to business ethics teaching (Jewe, 2008; Waples et al., 2009). These reveal mixed results (with a worrying trend in findings that those who enrol on business courses themselves start from a lower base of 'moral orientation' than humanities and science students). The relatively small amount of research that has been undertaken with actual working people (Clarke, 2011; Kirsten and Plessis, 2017) similarly reveals mixed results. It is important to note that most of these studies include self-report measures, thus offering questionable indications of what people actually do in the field.

Curiously, the key accreditors of business school programmes seem to be reluctant to champion the desirability of ethics within formal business education. Neither the Academy of Management nor the Association to Advance Collegiate School of Business require business schools they accredit to offer business ethics as part of their core curriculum (Floyd et al., 2013). A number of reasons are given for this omission, including the question about whether or not ethics can be taught.

Business schools themselves have been implicated in the growing numbers of organizations involved in cases of ethical malfeasance, including the financial crisis of 2007/08 (Giacalone and Wargo, 2009). Empirical work undertaken by Hummel et al. (2018) indicates that at the very least, business school education does not further moral development in students. They note how the emphasis placed on business models aimed at increasing profit encourages students to frame situations primarily in financial terms, rather than to adequately consider human and environmental costs, which can be difficult both to identify and measure.

What these studies fail to link up is the overarching neoliberal ideology in which business schools are embedded. I would argue that the real culprit here is the fundamental assumption that business models are the most important lens through which situations should be analysed. Ethics are often couched as standards which themselves must fit within market realities, rather than the other way around. As Clarke (2011) writes, those working in financial institutions who were selling worthless financial products and toxic loans implicated in the 2007 crash felt they were working 'within the boundaries of the free market system' (p. 2). The free market system is the frame through which ethics is considered, and more often than not the market trumps ethical considerations (Devinney, 2009). 
Indeed, Korten (1995) suggests that the rhetoric of business ethics and CSR enables businesses to think they are doing all right, when in fact their problematic ways of operating remain untouched. A more fundamental question offered by Sterba (2009) drives this debate: Should businesses be accountable to the same ethical regulations that individuals would be, or is their ethical responsibility due to only their shareholders? As the main generators of economic wealth, businesses have been allowed to rise above the moral landscape to which individuals are tethered. Lamberton (2011) asserts that if businesses continue to be able to act as amoral beings within the world, they will take the planet down with them. How might this worrying scenario be avoided?

\subsection{WHAT IS THE ROLE OF BUSINESS IN SUCH TIMES?}

To summarize the argument thus far: the dominant ideology of neoliberalism places financial concerns at the heart of human activity. This ideology imbues contemporary consciousness to such an extent that not only do we willingly accept the injunction to make money in order to enjoy material goods and services, our very lives are now produced and measured in terms of the 'human capital' we accrue. Such a skewed focus on markets and financial growth above all else has resulted in huge disparities in wealth, life-endangering global climate change and levels of workplace stress that leave significant numbers of us suffering from mental health issues.

Within this landscape, businesses in the USA and UK have assumed a central role, evidenced by reductions in tax liabilities over the last 30 years as well as a relaxation of regulations more generally. With the cap on political donations in the USA halted in 2014 businesses can now support politicians in ways that mean that elected government officials are often indebted to them. This, along with the huge amounts of money spent on lobbying, mean that business 'calls the tune' in terms of government policy as almost never before. In these ways, businesses have already 'stepped up' significantly beyond their roles as producers of goods and services and generators of meaningful work for human beings.

Within this analysis, Tim Cook's assertion that businesses need to 'step up' to assume the role that government can no longer fulfil reveals itself as hubristic. Moreover, given Apple's record in terms of tax avoidance, creation of products with inbuilt obsolescence and the kinds of working conditions many of its employees endure, it is also startlingly hypocritical. If 'stepping up' is dismissed as an appropriate strategy for businesses to 
follow in order to 'do good', what might they do instead to generate social value during these troubling times?

\subsubsection{Paying Taxes}

A key factor in the ineffectiveness of governments in the USA and UK is the loss of funds from corporations since the 1980s. Even in an era of favourable regulations, significant numbers of multinational companies regularly find ways of avoiding tax. For instance, although GE made $\$ 14.2$ billion in the tax year 2009-10 (\$5.1 billion of which was earned in the USA itself), it paid a tax bill of zero (Kocieniewski, 2011). Similarly, high-profit companies such as Amazon, Google and Facebook have come under public scrutiny for their tax avoidance strategies.

After considering the question relating to the ethics of tax avoidance from principle-based and utilitarian ethics, Dowling (2014) concludes that although tax avoidance may be legal, it is indeed unethical. Noting the extent to which tax avoidance has been missing from many discussions of CSR (tax avoidance is, after all, technically legal), he argues that paying taxes is the most basic form of citizenship behaviour, and that at the very least corporations should fulfil this duty. Especially when companies such as Amazon or Apple are making such extraordinary profits, it is hard to understand why not paying a fair proportion in tax should be considered acceptable.

It is the neoliberal ideology that imbues our culture that condones such action. Instead of seeing tax avoidance as 'wrong', it is conceived of as just doing 'smart business'. If the accepted rhetoric is that 'government is wasteful and inefficient', and businesses can do it better because of the efficiency of their processes, not adhering to this basic civic duty starts to make sense. What is important here is to recognize the way it is the discourse of neoliberalism, rather than the truth of businesses' inherent superiority, which is the basis for justification of the tax avoidance argument.

\subsubsection{Reduction in Waste and Care of Communities}

A second fundamental duty in our troubled times is for companies to reduce the amount of waste they produce and the amount of harm they cause to the environment in which they are located. This is in line with an approach to CSR based in 'doing no harm' rather than 'doing good' (Crilly et al., 2015). Waste products, be they obsolescent goods or the waste that is generated through creating them in the first place, create huge strains on the natural environment. Levels of both industrial and consumer waste continue to rise worldwide with the World Bank estimating that global waste will triple by 2100 (Goto, 2013). The importance of organizations 
living within ecological constraints and taking care to produce minimal waste has been asserted by ethics scholars such as Waddock (2004) who identifies care for the environment as a key accountability of businesses in any general standard of responsible corporate behaviour.

\subsubsection{Not Overworking, Stressing or Bullying Employees}

At the very least, a key responsibility for organizations is not to overwork and bully employees (Fleming, 2017). Yet, firms from Sports Direct in the UK to Amazon, to Apple regularly subject employees to overwork, bullying and stress. Work practices in which employees are expected to be available through smartphones 24/7 lead to depression, anxiety and mental illness. Certainly, a basic responsibility of business is to care for those who maintain its ability to produce its goods and services.

\subsection{CONCLUSION}

This chapter has argued that neoliberalism plays a leading role in generating the troubled times in which we live. As Fleming et al. (2013) stress, the problem with CSR and business ethics as approaches to curbing the worst of corporatism is that they don't recognize the 'structural nature of the capitalist economic imperative' (p. 340) that fuels our fixation with the market, economic growth and profit rather than people. Neoliberalism frames what we think of as possible, and perhaps more importantly it preordains what is 'important'. Consider the fact that so often when human lives are lost due to severe weather events, the ultimate calculation is rendered in relation to financial loss: so many days of work, the cost of rebuilding, the decline in productivity.

Such a realization suggests new directions of business ethicists. Rather than trying to increase individual commitment to ethical action, perhaps our efforts might best be spent critiquing the larger neoliberal agenda and how it informs everything that we do. Perhaps we should be spending more energy exposing the ways in which the emphasis on profit and reliance on the markets is causing the problems we are having. Perhaps it is important for us to remind those with whom we engage that the way things are is not the way things have to be: businesses have worked to different rules before and they can work to different rules in the future. Perhaps most importantly, we might remind ourselves and those we teach about the things that really matter: family, community and the ecological system which supports us. The importance and value of these aspects of our lives may well become increasingly clear as capitalism shakes itself apart. 


\section{REFERENCES}

BBC. (2018). Apple investigated by France for 'planned obsolescence'. Retrieved 8 October 2018 from https://www.bbc.co.uk/news/world-europe-42615378.

Belle, D. and Doucet, J. (2003). Poverty, inequality, and discrimination as sources of depression among U.S. women. Psychology of Women Quarterly, 27(2), 101-13. https://doi.org/10.1111/1471-6402.00090.

Boda, Z. and Zsolnai, L. (2016). The failure of business ethics. Society and Business Review, 11(1), 93-104. https://doi.org/10.1108/SBR-11-2015-0066.

CDC. (2018). Prescription opioid data. Retrieved 8 October 2018 from https:// www.livescience.com/62781-why-are-suicide-rates-rising.html.

Clarke, C. (2011). A system approach to implementing business ethics in the corporate workplace. Journal of Business Systems, Governance \& Ethics, 6(2), 1-11. Retrieved from http://library.gcu.edu:2048/login?url=http://search.ebscohost.com/login.asp $\mathrm{x}$ ?direct $=$ true $\& \mathrm{db}=\mathrm{bth} \& \mathrm{AN}=76973520 \&$ site $=$ eds-live $\&$ scope $=$ site $($ accessed 30 August 2019).

Clifford, C. (2018). Warren Buffet on the US Economy: 'The tsunami of wealth didn't trickle down. It surged upwards'. Retrieved on 19 December 2018 from https://www.cnbc.com/2018/01/04/warren-buffett-on-the-failure-of-trickle-downeconomics.html.

Coburn, D. (2000). Income inequality, social cohesion and the health status of populations: the role of neo-liberalism. Social Science \& Medicine, 51(1), $135-46$.

Colebrook, C. (2018). Unfair and in need of reform: public attitudes to the UK economy. Retrieved 9 October 2018 from https://www.ippr.org/research/publications/ unfair-and-in-need-of-reform.

Cox, M. (2017). The rise of populism and the crisis of globalisation: Brexit, Trump and beyond. Irish Studies in International Affairs, 28, 9-17.

Crilly, D., Ni, N., and Jiang, Y. (2015). Do no harm vs do good social responsibility: attribution theory and the labeling of foreignness. Strategic Management Journal, 37(7), 1316-29.

Devinney, T.M. (2009). Is the socially responsible corporation a myth? The good, the bad, and the ugly of corporate social responsibility. Academy of Management Perspectives, 23(2), 44-56. https://doi.org/10.5465/AMP.2009.39985540.

Dowling, G.R. (2014). The curious case of corporate tax avoidance: is it socially irresponsible? Journal of Business Ethics, 124(1), 173-84. https://doi.org/10.1007/ s10551-013-1862-4.

Drucker, J. and Bowen, S. (2017). After a tax crackdown, Apple find a new shelter for its profits. 6 November. Retrieved 4 October 2018 from https://www.nytimes. com/2017/11/06/world/apple-taxes-jersey.html.

Ehrenkranz, M. (2016). Apple employees say their mental health issues came from a hostile work environment. Retrieved 8 October 2018 from https://mic.com/articles /154788/apple-employees-say-their-mental-health-issues-came-from-alleged-host ile-work-environment\#.MeEnedhDt.

Fleming, P. (2017). The Death of Homo Economicus. London: Pluto Press.

Fleming, P., Roberts, J., and Garsten, C. (2013). In search of corporate social responsibility: introduction to special issue. Organization, 20(3), 337-48. https:// doi.org/10.1177/1350508413479581.

Floyd, L.A., Xu, F., Atkins, R., and Caldwell, C. (2013). Ethical outcomes and 
business ethics: toward improving business ethics education. Journal of Business Ethics, 117(4), 753-76. https://doi.org/10.1007/s10551-013-1717-z.

Fort, T.C., Pierce, J.R., and Schott, P.K. (2018). Manufacturing employment. Journal of Economic Perspectives, 32(2), 47-72.

Friedman, M. (1970). The social responsibility of business is to increase its profit. New York Times Magazine, 32-9.

Giacalone, R. and Wargo, D. (2009). The roots of the Global Financial Crisis are in our business schools. Journal of Business Ethics Education, 6, 147-68. Retrieved from http://www.emeraldinsight.com/doi/10.1108/SBR-11-2015-0066 (accessed 30 August 2019).

Goto,M.(2013). Globalwastetotripleby2100. Retrieved20December2018from http:// www.worldbank.org/en/news/feature/2013/10/30/global-waste-on-pace-to-triple.

Graham, C. and Felton, A. (2006). Inequality and happiness: insights from Latin America. Journal of Economic Inequality, 4(1), 107-22. https://doi.org/10.1007/ s10888-005-9009-1.

Hage, G. (2017). Is Racism an Environmental Threat? London: John Wiley \& Sons.

Hamann, T.H. (2009). Neoliberalism, governmentality, and ethics. Foucault Studies, 6, 37-59. https://doi.org/10.22439/fs.v0i0.2471.

Hummel, K., Pfaff, D., and Rost, K. (2018). Does economics and business education wash away moral judgment competence? Journal of Business Ethics, 150(2), $559-77$.

IPCC. (2018). Global warming of 1.5 degrees C. Retrieved 9 October 2018 from http://www.ipcc.ch/report/sr15/.

Jewe, R.D. (2008). Do business ethics courses work? The effectiveness of business ethics education: an empirical study. Journal of Global Business Issues, 2(1), $1-6$.

Kirsten, M. and Plessis, M. (2017). More does not always mean better: do more comprehensive ethics management programmes result in better outcomes? African Journal of Business and Economic Research, 12(2/3), 149-77.

Klein, N. (2014). This Changes Everything: Capitalism vs Climate. London: Allen Lane.

Kocieniewski, D. (2011). GEs strategies let it avoid taxes altogether. New York Times, 24 March.

Korten, D. (1995). When Corporations Rule the World. San Francisco, CA: Berrett-Koehler.

Ladkin, D. (2017). How did that happen? Making sense of the 2016 US presidential election result through the lens of the 'leadership moment'. Leadership, 13(4), 393-412. https://doi.org/10.1177/1742715017714841.

Lamberton, G.W. (2011). An ethical response to climate change. Journal of Business Systems, Governance \& Ethics, 6(2), 12-27.

Mejia, Z. (2017). Apple is giving $\$ 10,000$ to hurricane relief. How much has Tim Cook donated to other causes? Retrieved 4 October 2018 from https://www.cnbc. com/2017/09/13/apple-gives-10-million-to-hurricane-harvey-and-hurricane-irmarelief.html.

NAMI. (2018). Mental health by the numbers. Retrieved 8 October 2018 from https://www.nami.org/Learn-More/Mental-Health-By-the-Numbers.

Schrodt, P. (2016). The Apprentice made Donald Trump's presidential campaign possible. Retrieved 19 December 2018 from https://www.businessinsider.com/the-appren tice-paved-way-for-donald-trump-presidential-campaign-2016-11? $\mathrm{r}=\mathrm{UK} \& \mathrm{IR}=\mathrm{T}$.

Sidahmed, M.(2016). Claims of hate crimes possibly linked to Trumpelection reported 
across the US. Guardian. Retrieved 18 December 2018 from https://www.theguard ian.com/us-news/2016/nov/10/hate-crime-spike-us-donald-trump-president.

Smith, A. (1863). The Wealth of Nations: An Inquiry into the Nature and Causes of the Wealth of a Nation. Edinburgh: Blacks.

Sorkin, A. (2017). Apple's Tim Cook barnstorms for 'moral responsibility'. Retrieved 4 October 42018 from http://www.nytimes.com/2017/08/28/business/ dealbook/tim-cook-apple-moral-responsibility.html.

Sterba, J.P. (2009). Our basic human right is a right to liberty and it leads to equality. In J.P. Sterba (ed.), Ethics: The Big Questions, Malden, MA and Oxford: Blackwell, pp. 285-95.

Stockhammer, E. (2015). Rising inequality as a cause of the present crisis. Cambridge Journal of Economics, 39(3), 935-58. https://doi.org/10.1093/cje/bet052.

Vance, E. (2018). Why are suicide rates rising? Retrieved 8 October 2018 from https://www.livescience.com/62781-why-are-suicide-rates-rising.html.

Waddock, S. (2004). Creating corporate accountability: to make foundational principles corporate citizenship real. Journal of Business Ethics, 50(4), 313-27. Retrieved from http://amp.aom.org/cgi/doi/10.5465/AMP.2009.39985540 (accessed 30 August 2019).

Waples, E.P., Antes, A.L., Murphy, S.T., Connelly, S., and Mumford, M.D. (2009). A meta-analytic investigation of business ethics instruction. Journal of Business Ethics, 87(1), 133-51. https://doi.org/10.1007/s10551-008-9875-0.

Weaver, M. (2018). Hate crime surge linked to Brexit and 2017 terrorist attacks. Guardian. Retrieved 19 December 2018 from https:/www.theguardian.com/ society/2018/oct/16/hate-crime-brexit-terrorist-attacks-england-wales.

Webb, A. and Gurman, M. (2018). Apple returning overseas cash and pay $\$ 38$ billion tax bill. Retrieved 8 October 2018 from https://www.bloomberg.com/news/ articles/2018-01-17/apple-expects-38-billion-tax-bill-on-overseas-repatriated-cash.

Wilkinson, R.G. and Pickett, K.E. (2009). Income inequality and social dysfunction. Annual Review of Sociology, 35, 493-511.

Wolff, N. (2017). A Century of Wealth in America. Cambridge, MA: Harvard University Press. 